\title{
SENTIMENTALIDADES À MEIA-LUZ: MEMÓRIAS AUDITIVAS DO BOLERO DE MEADOS DO SÉCULO XX
}

\author{
AUTOR: BEATRIZ MELO DA SILVA \\ CO-AUTOR/ORIENTADOR: ANDRE DOMINGUES DOS SANTOS
}

Resumo: Iniciado em 2014 e centrado no arrocha, o presente trabalho tem se aproximado de grandes e raros trabalhos dedicados às obras musicais produzidas e consumidas pelas camadas mais desfavorecidas e distantes dos grandes centros urbanos nos últimos 30 anos. Em seu estágio atual, após encontrarmos no bolero hispano-americano um antecedente fundamental do arrocha, passamos a investigar sua trajetória no Brasil, transcorrida ao largo do cânone da chamada MPB. Dessa forma, este trabalho teve como objetivo investigar e qualificar o legado do bolero de meados do século XX para a cultura marginal relacionada ao arrocha, mas eventualmente reverberando nos cafonas da década de 1970. Do ponto de vista referencial, está firmado sobre um tripé teórico composto pela semiótica da canção, a história cultural e a antropologia urbana. Os anos 50 foram um período marcado por grandes produções musicais, entre canções românticas e carnavalescas. No entanto, tudo que derivava da cultura massiva era estigmatizado e rejeitado, especialmente o bolero. Ao percorrermos a bibliografia pertinente e nos dedicarmos à escuta e análise das obras encontradas, notamos grande destaque de artistas nesse período, os quais mantiveram ligação com o ritmo, sendo por isso qualificados eventualmente como "de mau-gosto", como Nelson Gonçalves, Altemar Dutra, Dircinha Batista, Maysa, Ângela Maria, Antônio Rago e a dupla Palmeira e Biá. O resultado das análises demonstraram uma predominância de recursos à passionalização, a exemplo de "Fica comigo esta noite", gravada por Nelson, "Sentimental demais", gravada por Altemar, "Nunca", composição de Lupicínio Rodrigues, interpretada por Dircinha, "Meu mundo caiu" interpretada por Maysa e, por último a composição de Rago, "Jamais te esquecerei", interpretada por ele mesmo no violão. Um recurso bastante utilizado também no arrocha, sobretudo nas interpretações do cantor e compositor Pablo, nas quais se encontra trechos com grande valorização à duração das notas, prolongando-as em sua maioria no agudo, que é a singularidade do artista. Esse prolongamento de notas foi também a principal característica da passionalização verificada nas canções dos artistas analisados. Esse predomínio do recurso à passionalização resulta em uma predominância da parte romântica, aparecendo muito mais do que a parte rítmica e exótica, ainda que se veja o uso de um bongô ou maraca em uma canção ou outra, mas nada que seja radicalmente antinacional e estranho a tradição brasileira.

Palavras-chave: Bolero, arrocha, música popular brasileira. 